\title{
Size Effect on Company Profitability: Evidence from Jordan
}

\author{
Firas Naim Dahmash ${ }^{1}$ \\ ${ }^{1}$ Accounting Department, the World Islamic Sciences \& Education University, Amman, Jordan \\ Correspondence: Firas Naim Dahmash, Accounting Department, the World Islamic Sciences \& Education \\ University, Amman, Jordan. E-mail: firas_dahmash@hotmail.com
}

Received: October 6, 2013

Accepted: May 20, 2014

Online Published: January 20, 2015

doi:10.5539/ijbm.v10n2p58

URL: http://dx.doi.org/10.5539/ijbm.v10n2p58

\begin{abstract}
This paper tested the size effectiveness on company profitability for the Jordanian context through applying two different models for a large sample of (1538) companies listed in Amman Security Exchange covering the period between 2005 and 2011. The results of the analysis indicated a highly significant value for the three main sectors of the sample. The highest significant value result was for the industrial sector companies, followed by the services sector companies, and lastly the financial sector companies. The results of the detailed industry analysis concerning the whole sub-sectors were similar with the highest values for the food and beverages companies, the commercial and educational services companies, and the insurance companies. The results indicated that the bank companies, the diversified financial companies, and the real estate companies have insignificant coefficient values for the total assets with company size. However, the bank companies only were insignificant for the total revenues coefficient of the company size. Finally, the results of the additional analysis of the top and bottom $30 \%$ indicated that the financial sub-sample were insignificant, and inconsistent with the results of the main financial sub-sample companies.
\end{abstract}

Keywords: company size, profitability, emerging markets, Jordan

\section{Introduction}

Company size is considered an important issue in determining the nature of relationship for the company within its operating environment and outside it, and the growing influences of the multinational corporations worldwide represents a clear example of the importance of size and the role it can plays in the corporate environment (Abiodun, 2013). The positive relation between company size and profitability was theoretically supported by the economies of scale concept, and this justification was prominent in the previous works of Alexander (1949), Stekler (1964), Hall and Weiss (1967) and Scherer (1973). Large companies are able to benefit from the economies of scale (the average unit cost declines over a range of output), and from the economies of scope (an extra cost savings as a result of the production process where separate products can share some production facilities). On the other hand, large companies are able to benefit from the superior management and the superior capabilities in product development, marketing, commercialization, financial scope, specialization, stronger bargaining power, stronger competitive power, bigger market share, and a more opportunity to work in the fields which require high capital rates since they have much more resources and this situation provides them the opportunity to work in more profitable fields with little competition. In the other hand, large companies have more ability for diversification in their related and unrelated units and it have also more capital cost saving which generates more sales in return (Dogan, 2013; Bayyurt, 2007; Helfat et al., 2007; Jonsson, 2007; Fiegenbaum \& Karnani, 1991; Ravenscraft \& Scherer, 1987).

Rajan and Zingales (1995) concluded in their study of 40 countries that most of the growth in their industrial sectors, during the 1980s, was a result of increase in size of particular firms.

The influence of the company size has been much queried in the area of corporate finance, and in the same time, the phenomenon of the company size is still rising within the external business environments, and there are more interests about how the company size effects on its internal structures and its impact on the relationship between the company and shareholders, and the rule of the company size as a fundamental variable in explaining the company profitability (Abiodun, 2013). The effects of company size on profitability have been addressed in current literature and most of these studies found a significant and positive relationship between company size and profitability (Serrasqueiro et al., 2008; Wu, 2006).

This study will be oriented to test the effectiveness of size as a vital variable on the company's profitability in the 
Jordanian context by using the total assets and the total revenues separately as indicators for size, and the return on assets ratio as indicator for profitability. The population of the study contains all the companies listed in Amman Security Exchange between the years from 2005 to 2011. It is interesting to see the effectiveness of size for a different types of companies from different sectors on profitability, and to see also company's size effect on profitability for all the sub-sector companies of these different sectors, and does these different sectors and their different sub-sectors shows a similar results or not?

In this context, this study will contribute to the literature by investigated the effectiveness of size on profitability for the whole different types of public companies through a detailed industry analysis for an emerging market over a period of seven years.

\section{Previous Research}

The effect of company size on profitability issue has been addressed by different international studies. These studies which were applied worldwide, mostly have been used the return on assets ratio or the net profit or both of them as a measures for profitability, and both of total assets and total sales, and in some studies the number of employees as a measures for company size for a different time periods, different sample sizes, and a different company sectors.

Abiodun (2013) tested the effect of the size of the company on its profitability for the manufacturing companies listed in the Nigerian Stock Exchange during the period between the year 2000 to 2009 and he found a significant positive relationship between size measures and profitability. In a similar study with a bigger sample, Dogan (2013) who used the data of 200 companies listed in Istanbul Stock Exchange (ISE) for the years from 2008 to 2011 found a significant positive relationship between size measures and profitability. Saliha and Abdessatar (2011) tested the factors affecting profitability of 40 companies operating in Tunisia for the period between the 1998 and 2006, and their results showed a significant and positive relation between the size of the company and its profitability. Another Turkish study by Karadeniz and İskenderoğlu (2011) has analyzed the variables affecting the return on assets of the tourism companies listed in ISE, and the findings also revealed positive and statistically significant relations between total assets and size.

The other similar previous studies also indicated the same results, but these studies used a more integrated samples. For example, Stierwald (2009) investigated the factors influencing the profitability for 960 big Australian companies for the period between the year 1995 and 2005. The findings revealed that company size affects company profitability positively. Another similar US study by Lee (2009) applied on 7000 US firms during the years between 1987 and 2006 have also found a significant and positive relation between the size and profitability. In the same manner, an older study by Fiegenbaum and Karnani (1991) used approximately 3000 companies' data from 83 sectors between the years of 1979 to 1987, and the results also indicated a significant and positive relationship between company size and profitability. Lastly, an old study by Hall and Weiss (1967) which used Fortune 500 companies in the US has also indicated a significant and positive relation between company size and profitability.

In the contrary, some other similar studies found a week relationship between company size and profitability, or found no relationship between company size and profitability, or found insignificant and negative relationship between company size and profitability for one or more sector companies. A recent study by Niresh and Velnampy (2014) explored the effects of firm size on profitability for 15 manufacturing companies active in Colombo Stock Exchange (CSE) for the period from 2008 to 2012 has found no relationship between firm size and profitability, and size has no profound impact on profitability. In another recent study, Banchuenvijit (2012) studied the factors affecting performances of Vietnamese companies; the results indicated a significant negative relation between total assets and profitability and no significant relationship between number of employees and profitability. Jonsson (2007) investigated the relation between company size and its profitability for 250 companies consisting banks, fish processing companies, and civil engineering consulting companies in Iceland over the period between 2000 and 2004. Jonsson (2007) also found a negative and weak relationship between the company size and its profitability for all the companies of the study irrespective the proxies used for size and profitability, except a weak positive relation was found for the bank companies. Another European study by Goddard, Tavakoli and Wilson (2005) investigated the relation between company and profitability, and also between company size and market share for manufacturing and service companies located in four European countries for the period between 1993 and 2001. The study revealed that the increase in the company size tend to reduce its profitability. However, any increase in market share was associated with another increase on company profitability. Goddard, Molyneux and Wilson (2004) also tested the profitability of European banks during the 1990s. The results showed a weak relationship between company size and profitability. However, Majumdar 
(1997) tested the effect of the company size and the company age on its profitability level for 1020 Indian companies, and the results of his study indicated that big firms have a higher profitability compared to small firms. Lastly, an old study by Shepherd (1972) has found a significant but negative relationship between company size and profitability.

Given the previous research results, it is interested to see the effectiveness of the Jordanian company's size on its profitability for the different industry types of public companies through a detailed industry analysis, and to see if the results are similar or not between the different sectors and the different sub-sectors over the period of the study.

\section{Methodology}

The main research question of this study is as follows:

Does the Jordanian company size have an effect on its profitability during the period of study?

This main research question can be answered through the following three sub-questions:

1) Does the Jordanian company size have an effect on its profitability for all the companies of the study during the period of study?

2) Is the effect of the company size on its profitability different for the different industry sectors during the period of study?

3) Is the effect of the company size on its profitability different for the different sub-sectors during the period of study?

4) Is the effect of the company size on its profitability different for the top $30 \%$ companies of the same industry sectors comparing with the bottom $30 \%$ companies of the same industry sectors during the period of study?

In order to answer the above three sub-questions of the main research question of this study, this study will follow the previous studies of (Abiodun, 2013; Dogan, 2013; Banchuenvijit, 2012; Saliha \& Abdessatar, 2011; Jonsson, 2007) by using a two different measures for the company size, and these measures are the logarithm of total assets and the logarithm of total revenues. Previous studies used the natural logarithm of total sales mostly for the merchant firms as a measure for size, and because this study will be applied on all types of industries, the total revenues for every firm will be calculated and used and not just the total sales as it was used in the previous studies. The firm's profitability will be measured by using the ratio of the return on total assets (ROA). This measure was used widely for the same purpose by many previous studies (Abiodun, 2013; Dogan, 2013; Banchuenvijit, 2012; Karadeniz \& İskenderoğlu, 2011; Saliha \& Abdessatar, 2011; Jonsson, 2007). In addition to the size and profitability measures, this study will add another variable which is the total liabilities to total assets ratio (leverage ratio), and this ratio will be used as a control variable for the two models of this study, and this procedure was used by (Abiodun, 2013; Dogan, 2013). Based on that, this study will test the effect of the company size on its profitability through applying the following two regression models every one alone which are as follows:

$$
\begin{gathered}
R O A_{i t}=a_{0}+\beta_{1} L_{T A}+\beta_{2} L E V_{i t}+e_{i t} \\
R O A_{i t}=a_{0}+\beta_{1} \text { LTRev }_{i t}+\beta_{2} L E V_{i t}+e_{i t}
\end{gathered}
$$

Where:

$R O A_{i t}$ : Return on total assets ratio of the company at year ${ }_{i t}$ (defined as net income before interest and taxes of the company at year ${ }_{i t}$ divided by total assets of the company at year ${ }_{i t}$ ),

$L T A_{i t}$ : Natural logarithm of total assets of the company at year ${ }_{i t}$,

LTRev $_{i t}$ : Natural logarithm of total revenues of the company at year ${ }_{i t}$

$L E V_{i t}$ : Leverage ratio of the company at year ${ }_{i t}$ (defined as total liabilities of the company at year ${ }_{i t}$ divided by total assets of the company at year ${ }_{i t}$ ),

$a_{0}$ : The constant,

$e_{i t}$ : The error term.

This study will compare between the above two mentioned models through applying them on the main sample of the study, and the other divided sub-samples of the study during the period of the study.

The researcher will follow the previous studies by using an unbalanced panel regression analysis for this study, 
and this study also will follow (Dahmash, 2013) by using the same divisions of the industrial, services and financial sectors and sub-sectors of the Jordanian companies used in this study.

The data of the study were collected from the annual published financial data of these companies as it is at the end of December (fiscal year) from the Amman Security Exchange website, and this data was covered all the Jordanian public companies which are listed on Amman Security Exchange during the of the study.

The sample of the study started with 1655 observations. However, the final sample was equal to 1538 observations which were selected as shown in Table 1 below.

Table 1. Selected sample

\begin{tabular}{ll}
\hline Years & $2005-2011$ \\
\hline Initial number of company years & 1655 \\
Less: & 117 \\
companies with unavailable or missing data & 1538 \\
\hline
\end{tabular}

Table 2. Descriptive statistics

\begin{tabular}{lcccc}
\hline (Variables) & ROA $_{i t}$ & LTA $_{i t}$ & LTRev $_{i t}$ & LEV $_{i t}$ \\
\hline Sample years (2005-2011) & & & & \\
$N=1538$ & 2 & 7 & 7 & 38 \\
Mean & 11 & 1 & 1 & 33 \\
Standard Deviation & -103 & 5 & 2 & -54 \\
Minimum & 61 & 10 & 9 & 576 \\
Maximum & & & & \\
\hline
\end{tabular}

Table 2 above reports the descriptive statistics for the variables which were used in the analysis as it is reported in next table. $\mathrm{ROA}_{i t}$ is the company's return on total assets ratio at year $\left({ }_{i t}\right), \mathrm{LTA}_{i t}$ is the company's logarithm of total assets at year $\left.{ }_{i t}\right), \operatorname{LTRev}_{i t}$ is the company's logarithm of total revenues at year $\left({ }_{i t}\right)$, and $\mathrm{LEV}_{i t}$ is the company's leverage ratio at year $(i t)$.

\section{Results and Discussion}

The descriptive statistics of the main four variables are presented at Table 2 above. The data covers most of the listed companies, and these companies are different in size, industry, and profitability; the return on total assets ratio variable of the whole sample ranges from a minimum high negative ratio of $-103 \%$ to a maximum high positive ratio of $61 \%$ comparing to a small mean which equal to $2 \%$ only, and an approximately high standard deviation $11 \%$, which indicated a clear differences in the return on total assets ratio between the companies of the study. The logarithm of total assets variable of the whole sample has a rational descriptive statistics values. The variable ranges from a minimum of 5 to a maximum of 10 and a mean equal to 7 , and a low standard deviation value equal to $1 \%$. The descriptive statistics of the logarithm of total revenues are not far comparing to the descriptive statistics of the variable of the logarithm of total assets. The logarithm of total revenues of the pooled sample ranges from a minimum of 2 to a maximum of 9 , and the values for the mean and the standard deviation are the same as the logarithm of total assets. Finally, the leverage variable of the whole sample ranges from a minimum of $-54 \%$ to a high maximum value of $576 \%$ and a mean equal to $38 \%$, and a standard deviation equal $33 \%$.

Table 3 presents the analysis results for the main pooled sample and its three sub-samples through using Equation (1) as it is mentioned above using unbalanced panel regression analysis which is corrected for potential heteroscedasticity following (White, 1980). 
Table 3. Assessing the effect of size on profitability using the first model

\begin{tabular}{lllll}
\hline Years & $(2005-2011)$ & $(2005-2011)$ & $(2005-2011)$ & $(2005-2011)$ \\
\hline & Pooled Sample & $\begin{array}{l}\text { Industrial Sector } \\
\text { Sample }\end{array}$ & $\begin{array}{l}\text { Services Sector } \\
\text { Sample }\end{array}$ & $\begin{array}{l}\text { Financial Sector } \\
\text { Sample }\end{array}$ \\
\hline $\begin{array}{l}\text { Observations } \\
\text { Number: }\end{array}$ & 1538 & 485 & 362 & 637 \\
Constant (C) & -29.048 & -59.746 & -27.663 & -12.856 \\
t-statistic (Ho: 0) & -8.88 & -7.357 & -2.612 & -2.63 \\
p-value & 0 & 0 & 0 & 0 \\
LTA & 4.774 & 9.249 & 4.661 & 2.355 \\
t-statistic (Ho: 0$)$ & 10.438 & 8.164 & 3.355 & 3.265 \\
p-value & 0 & 0 & 0 & 0 \\
LEV & -0.11 & -0.153 & -0.111 & -0.071 \\
t-statistic (Ho: 0$)$ & -9.379 & -6.718 & -5.527 & -3.249 \\
p-value & 0 & 0 & 0 & 0 \\
Adj R Sq & 0.197 & 0.401 & 0.394 & 0.208 \\
F-Statistic & 2.342 & 5.007 & 4.856 & 2.515 \\
\hline
\end{tabular}

Table 3 showed that the regression results for the pooled sample (all sectors sample). The logarithm of total assets coefficient $\left(\mathrm{LTA}_{i t}\right)$ of the pooled sample as it is in Table 3 is significant, and it is equal to 4.774 which indicates a high impact for the size on profitability for the Jordanian listed companies during the period from 2005 to 2011, and that's mean that the profitability of the company increases as the total assets of it increase.

This result is similar to the previous studies results used the same variables (Abiodun, 2013; Dogan, 2013; Karadeniz \& İskenderoğlu, 2011; Saliha \& Abdessatar, 2011; Lee, 2009; Stierwald, 2009; Serrasqueiro \& Nunes, 2008; Özgülbaş et al., 2006; Majumdar, 1997).

The coefficient of the leverage variable $\left(\mathrm{LEV}_{i t}\right)$ is also significant but indicated a negative relationship with the firm profitability -0.11 , which means that any increase in the financial leverage will decrease the profitability and vice versa, and this result confirm previous studies used the same leverage variable (Abiodun, 2013; Dogan, 2013).

Another similar analysis was done for the industrial, services and financial sub-samples in order to see if the industry structure shows any changes in the results for the company size effect on its profitability. The next second, third, and fourth sub-samples in Table 3 above shown a consistency results with the results of the first pooled sample, and that's included the coefficients values of the company's size, and the leverage control variable coefficients values for all these three sub-samples, and also the (Adjusted $R^{2}$ ) values.

Table 3 revealed that the company's size coefficient represented by the logarithm of total assets variable $\left(\mathrm{LTA}_{i t}\right)$ of the pooled sample is higher than the other two coefficients of the company's size $\left(\mathrm{LTA}_{i t}\right)$ of the services and the financial sectors. However, the company's size coefficient $\left(\mathrm{LTA}_{i t}\right)$ of the pooled sample is less than the company's size coefficient $\left(\mathrm{LTA}_{i t}\right)$ of the industrial sector.

The value of company's size coefficient $\left(\mathrm{LTA}_{i t}\right)$ of the pooled sample is 4.774 , which is higher by 0.113 comparing to the same coefficient of the services sector and higher by 2.419 comparing the same coefficient of the financial sector. However, it is lower by 4.475 comparing to the same coefficient of the industrial sector. The leverage control variable coefficient $\left(\mathrm{LEV}_{i t}\right)$ is similar and consistent with the first pooled sample result.

The pooled sample regression result has a moderate (Adjusted $\mathrm{R}^{2}$ of $19.7 \%$ ); which means that the profitability is affected by size, and this result is still consistent with the previous studies of (Abiodun, 2013; Dogan, 2013; Karadeniz \& İskenderoğlu, 2011; Saliha \& Abdessatar, 2011; Lee, 2009; Stierwald, 2009; Serrasqueiro \& Nunes, 2008; Özgülbaş et al., 2006; Majumdar, 1997).

A similar regression analysis was made for the pooled sample and the other next three sub-samples by using the logarithm of total revenues $\left(\operatorname{LTRev}_{i t}\right)$ as another proxy for size.

Table 4 presented the regression results of the pooled sample. These results were also similar to the previous regression results of the first model as it is in Table 3 and also indicating that the company's size coefficient of 
the logarithm of total revenues $\left(\operatorname{LTRev}_{i t}\right)$ is still significant, and this result is similar to previous results in the studies used the same variables (Abiodun, 2013; Dogan, 2013; Karadeniz \& İskenderoğlu, 2011; Saliha \& Abdessatar, 2011; Lee, 2009; Stierwald, 2009; Serrasqueiro \& Nunes, 2008; Özgülbaş et al., 2006; Majumdar, 1997).

The logarithm of total revenues coefficient $\left(\operatorname{LTRev}_{i t}\right)$ of the pooled sample in Table (3) has also a high significant positive value equal to 5.058 which also indicating a high impact for the size on profitability for the companies of the study, and that's mean that the profitability increases as the total revenues of it increase, and this result is similar to what was indicated by the total assets proxy of size as indicated in Table (3). The result of the leverage coefficient $\left(\mathrm{LEV}_{i t}\right)$ is still consistent with the previous results.

Based on the previous regression analysis results the first research sub-question of this study, can be answered by yes the Jordanian company size has an effect on its profitability.

The analysis was continued to answer the second and third research sub questions, and in order to do that another similar detailed regression analysis for the sub-sectors was done for the logarithm of total assets variable with profitability for the same first, second and third sector sub-samples companies, in order to see if the industry structure shows any changes in the results for the company size effect on its profitability.

The next three sub-samples in Table 4 above indicated a consistent regression results with the first pooled sample regression results, and that's also included the logarithm of total revenues and the leverage coefficients values for these companies of the three mentioned sectors sub-samples, with the (Adjusted $\mathrm{R}^{2}$ ) values.

Table 4 revealed that the pooled sample size coefficient of the logarithm of total revenues $\left(\operatorname{LTRev}_{i t}\right)$ is higher by 0.446 comparing to the same coefficient of the financial sector, but it is lower by 1.47 and 0.048 comparing to the same coefficients of the industrial and services sectors respectively. The leverage coefficient is still as before.

The pooled sample regression results has also a good explanatory power (Adjusted $\mathrm{R}^{2}$ of $27.4 \%$ ); indicated that the profitability is affected by size, and this result is higher by $7.7 \%$ comparing to the Adjusted $\mathrm{R}^{2}$ result of the previous analysis as shown in Table 3 above. This result is still consistent with the previous studies.

Table 4. Assessing the effect of size on profitability using the second model

\begin{tabular}{|c|c|c|c|c|}
\hline Years & $(2005-2011)$ & $(2005-2011)$ & $(2005-2011)$ & $(2005-2011)$ \\
\hline & & Industrial Sector & Services Sector & Financial Sector \\
\hline & Pooled Sample & Sample & Sample & Sample \\
\hline \multicolumn{5}{|l|}{ Observations } \\
\hline Number: & 1538 & 485 & 362 & 637 \\
\hline Constant (C) & -27.398 & -37.758 & -27.75 & -23.569 \\
\hline t-statistic (Ho: 0 ) & -11.057 & -7.383 & -3.354 & -6.549 \\
\hline p-value & 0 & 0 & 0 & 0 \\
\hline $\operatorname{LRev}_{\text {it }}$ & 5.058 & 6.528 & 5.106 & 4.612 \\
\hline t-statistic (Ho: 0$)$ & 13.459 & 8.727 & 5.686 & 7.365 \\
\hline $\mathrm{p}$-value & 0 & 0 & 0 & 0 \\
\hline $\mathrm{LEV}_{\text {it }}$ & -0.115 & -0.159 & -0.121 & -0.106 \\
\hline t-statistic (Ho: 0$)$ & -10.546 & -7.226 & -5.912 & -5.491 \\
\hline $\mathrm{p}$-value & 0 & 0 & 0 & 0 \\
\hline Adjusted $\mathrm{R}^{2}$ & 0.274 & 0.418 & 0.439 & 0.308 \\
\hline F-Statistic & 3.06 & 5.299 & 5.627 & 3.578 \\
\hline
\end{tabular}

Again, and in the same manner, another detailed analysis for the three mentioned sub-sectors was done for the first, second and third sub-sample sectors to see the effect of the industry structure if any, for every sub-sample companies through using the first model then the second model of this study respectively.

Table 5 shows the regression analysis for the industrial sub-sector companies using the first model which contains the logarithm of total assets variable as a proxy for size. Table 5 shows that the highest coefficient value $\left(\mathrm{LTA}_{i t}\right)$ was for the food and beverages sub-sector companies, followed by the printing and packaging industrial 
sub-sector companies, then the constructing and extracting companies, and finally, the chemical and pharmaceutical industrial companies. The leverage coefficient is still consistent except for the chemical and pharmaceutical industrial sub-sector sample, which was insignificant.

Table 5. Assessing the effect of size on profitability of industrial sub-sector firms using the first model

\begin{tabular}{|c|c|c|c|c|}
\hline Years & $(2005-2011)$ & $(2005-2011)$ & $(2005-2011)$ & $(2005-2011)$ \\
\hline & Chemical \& & Construction \& & Food \& & Printing \& \\
\hline & Pharmacetical & Extracting & Beverages & Backaging \\
\hline & Sub-Sector & Sub-Sector & Sub-Sector & Sub-Sector \\
\hline & Companies & Companies & Companies & Companies \\
\hline \multicolumn{5}{|l|}{ Observations } \\
\hline Number: & 111 & 194 & 134 & 46 \\
\hline Constant (c) & -40.264 & -59.285 & -71.649 & -65.378 \\
\hline t-statistic (Ho: 0) & -2.737 & -5.743 & -6.44 & 6.265 \\
\hline $\mathrm{p}$-value & 0.008 & 0 & 0 & 0 \\
\hline $\mathrm{LTA}_{\text {it }}$ & 6.112 & 9.327 & 10.704 & 10.372 \\
\hline t-statistic (Ho: 0) & 2.906 & 6.489 & 6.975 & 7.412 \\
\hline p-value & 0.005 & 0 & 0 & 0 \\
\hline $\mathrm{LEV}_{\text {it }}$ & -0.0562 & -0.197 & -0.115 & -0.194 \\
\hline t-statistic (Ho: 0) & -0.926 & -6.984 & -3.128 & -3.569 \\
\hline $\mathrm{p}$-value & 0.357 & 0 & 0 & 0.001 \\
\hline Adjusted $\mathrm{R}^{2}$ & 0.019 & 0.58 & 0.415 & 0.646 \\
\hline F-Statistic & 1.09 & 5.698 & 4.364 & 6.467 \\
\hline
\end{tabular}

Table 6 shows the analysis for the industrial sub-sector companies using the second model of the logarithm of total revenue as a proxy for size. Table 6 shows that the regression results are not similar for the industrial sub-sector companies. The highest coefficient value was for the constructing and extracting companies, followed by the industrial sub-sector of the chemical and pharmaceutical industrials, then the food and beverages companies sub-sector, and finally, the printing and packaging industrial sub-sector companies. The leverage coefficient is consistent.

Table 6. Assessing the effect of size on profitability of industrial sub-sector firms using the second model

\begin{tabular}{lllll}
\hline Years & $(2005-2011)$ & $(2005-2011)$ & $(2005-2011)$ & $(2005-2011)$ \\
\hline & Chemical \& & Construction \& & Food \& & Printing \& \\
& Pharmacetical & Extracting & Beverages & Backaging \\
& Sub-Sector Companies & Sub-Sector Companies & Sub-Sector Companies & Sub-Sector Companies \\
\hline Observations & & & & \\
Number: & 111 & 194 & 134 & 46 \\
Constant (c) & -40.634 & -46.581 & -37.203 & -22.354 \\
t-statistic (Ho: 0) & -4.205 & -5.54 & -5.712 & 1.755 \\
p-value & 0 & 0 & 0 & 0.09 \\
LTRev it & 6.686 & 7.717 & 6.521 & 4.618 \\
t-statistic (Ho: 0) & 4.475 & 6.454 & 6.617 & 2.418 \\
p-value & 0 & 0 & 0 & 0.022 \\
LEV & -0.076 & -0.156 & -0.169 & -0.217 \\
t-statistic (Ho: 0$)$ & -1.416 & -5.85 & -4.916 & -2.229 \\
p-value & 0.16 & 0 & 0 & 0.01 \\
Adjusted R & 0.202 & 0.371 & 0.399 & 0.249 \\
F-Statistic & 7.74 & 4.077 & 4.15 & 1.994 \\
\hline
\end{tabular}


The analysis was repeated for the services sub-sector sample companies were for the first and second models of the study.

Table 7 below shows the analysis for the services sub-sector companies for the same period of the study (2005-2011) using the first model. It is noted that the highest company size coefficient value was for the commercial and educational services companies, followed by the transportation services sub-sector companies, then followed by the tourism and health care companies, and finally, was the results of the utilities and communication companies. The leverage variable is still consistent except for the tourism and health care companies.

Table 7. Assessing the effect of size on profitability of services sub-sector firms using the first model

\begin{tabular}{|c|c|c|c|c|}
\hline Years & $(2005-2011)$ & $(2005-2011)$ & $(2005-2011)$ & $(2005-2011)$ \\
\hline & & Transportation \& & Tourism \& Health & \\
\hline & Utilities \& & Services & Care & \\
\hline & Communications & Sub-Sector & Sub-Sector & Commercial \& Educational Services Sub-Sector \\
\hline & Sub-Sector Companies & Companies & Companies & Companies \\
\hline \multicolumn{5}{|l|}{ Observations } \\
\hline Number: & 56 & 78 & 100 & 128 \\
\hline Constant (c) & -27.338 & -38.364 & -43.954 & -57.684 \\
\hline t-statistic & & & & \\
\hline (Ho: 0$)$ & -1.887 & -2.544 & -3.127 & -3.665 \\
\hline p-value & 0.067 & 0.014 & 0.003 & 0 \\
\hline $\begin{array}{l}\mathrm{LTA}_{\text {it }} \\
\text { t-statistic }\end{array}$ & 4.65 & 6.816 & 5.981 & 9.935 \\
\hline (Ho: 0 ) & 2.703 & 3.085 & 3.476 & 4.315 \\
\hline p-value & 0.01 & 0.003 & 0 & 0 \\
\hline $\begin{array}{l}L^{2} V_{\text {it }} \\
\text { t-statistic }\end{array}$ & -0.1 & -0.213 & 0.009 & -0.314 \\
\hline (Ho: 0) & -5.524 & -3.754 & 0.134 & -4.57 \\
\hline p-value & 0 & 0 & 0.894 & 0 \\
\hline Adjusted $\mathrm{R}^{2}$ & 0.543 & 0.392 & 0.105 & 0.366 \\
\hline F-Statistic & 4.63 & 3.367 & 1.106 & 3.712 \\
\hline
\end{tabular}

Table 8 shows the analysis for the services sub-sector companies for the same period using the same second model. The regression results are also not similar.

The highest coefficient value was for the educational services sub-sector companies, followed by the transportation services sub-sector, and these results are similar and consistent with the previous results of Table 7 . The utilities and communication companies were the third best results; finally, the coefficient value of the tourism and health care sub-sector companies. The leverage variable is still consistent except for the tourism and health care companies, and this is consistent with the previous result as shown in Table 7 above. 
Table 8. Assessing the effect of size on profitability of services sub-sector firms using the second model

\begin{tabular}{|c|c|c|c|c|}
\hline Years & $(2005-2011)$ & $(2005-2011)$ & $(2005-2011)$ & $(2005-2011)$ \\
\hline & Utilities \& & Transportation \& & Tourism \& Health & \\
\hline & Communications & Services & Care & \\
\hline & Sub-Sector & Sub-Sector & Sub-Sector & Commercial \& Educational Services Sub-Sector \\
\hline & Companies & Companies & Companies & Companies \\
\hline \multicolumn{5}{|l|}{ Observations } \\
\hline Number: & 56 & 78 & 100 & 128 \\
\hline Constant (c) & -26.07 & -25.267 & -22.237 & -32.012 \\
\hline t-statistic (Ho: 0$)$ & -2.04 & -2.478 & -3.458 & -4.194 \\
\hline p-value & 0.05 & 0.016 & 0 & 0 \\
\hline $\operatorname{LTRev}_{\text {it }}$ & 4.583 & 5.257 & 3.507 & 6.626 \\
\hline t-statistic (Ho: 0$)$ & 2.967 & 3.353 & 4.104 & 5.844 \\
\hline p-value & 0.005 & 0.001 & 0 & 0 \\
\hline $\mathrm{LEV}_{\text {it }}$ & -0.102 & -0.203 & 0.009 & -0.265 \\
\hline t-statistic (Ho: 0$)$ & -5.814 & -3.908 & 0.141 & -3.938 \\
\hline p-value & 0 & 0 & 0.888 & 0 \\
\hline Adjusted $\mathrm{R}^{2}$ & 0.558 & 0.427 & 0.112 & 0.418 \\
\hline F-Statistic & 4.862 & 3.734 & 1.545 & 4.377 \\
\hline
\end{tabular}

The previous results of the industrial and services sub-sector companies indicated a strong effect for the size represented by total assets and total revenues on profitability, which means that company size, has a positive impact on profitability for these tested companies.

As for the industrial and services sub-sector companies, also the same unbalanced panel regression analysis for the financial sub-sector companies was made using the same first and second models of the study.

Table 9, below shows the detailed financial sub-sector company analysis for the same period (2007-2011). It shows a different regression results for the different financial sub-sector companies samples.

Table 9. Assessing the effect of size on profitability of financial sub-sector firms using the first model

\begin{tabular}{lllll}
\hline \multicolumn{1}{c}{ Years } & $(2005-2011)$ & $(2005-2011)$ & $(2005-2011)$ & $(2005-2011)$ \\
& Bank & $\begin{array}{l}\text { Diversified Financial } \\
\text { Sub-Sector Companies }\end{array}$ & $\begin{array}{l}\text { Insurance } \\
\text { Sub-Sector Companies }\end{array}$ & $\begin{array}{l}\text { Real state } \\
\text { Sub-Sector Companies }\end{array}$ \\
\hline Observations Number: & & & & \\
& 112 & 181 & 161 & 183 \\
Constant (c) & 5.664 & -25.996 & -67.474 & 2.697 \\
t-statistic (Ho: 0) & 2.222 & -1.522 & -2.819 & 0.346 \\
p-value & 0.029 & 0.13 & 0.006 & 0.73 \\
LTA & -0.172 & 3.936 & 10.226 & 0.134 \\
t-statistic (Ho: 0) & -1.14 & 1.684 & 2.906 & 0.12 \\
p-value & 0.257 & 0.094 & 0.004 & 0.905 \\
LEV & -0.0294 & -0.02 & -0.111 & -0.03 \\
t-statistic (Ho: 0$)$ & -1.305 & -0.51 & -1.651 & -915 \\
p-value & 0.195 & 0.611 & 0.101 & 0.362 \\
Adjusted $\mathrm{R}^{2}$ & 0.302 & 0.218 & 0.373 & 0.079 \\
F-Statistic & 3.089 & 2.356 & 3.882 & 1.389 \\
\hline
\end{tabular}

Table 9 above shows that the highest company size coefficient was for the insurance companies. However, Table 9 shown that the coefficient values of the banks companies, diversified financial companies, and the real state companies sub-sectors are insignificant. These results are not consisted with the previous results of the industrial and the services sub-sectors. The coefficient of the leverage variable is still insignificant.

Table 10 below shows the other analysis of the sub-sector financial companies for the same period (2005-2011) using the second model. Table 10 shows differences in the regression results for the financial sub-sector companies comparing to the previous regression results of Table 9. 
Table 10 indicated also a significant coefficient value for the diversified financial sub-sector companies, the insurance sub-sector companies, and the real estate sub-sector companies. However, Table 9 shown insignificant coefficient value for the company size of the diversified financial sub-sector companies, and the real estate sub-sector companies. Table 10 indicated that the diversified financial sub-sector companies have the highest company size coefficient value, followed by the insurance sub-sector companies, and then the real estate sub-sector companies, and finally the banks sub-sector companies which have insignificant coefficient value.

The results are insignificant and it is indicated a negative insignificant relationship with the company profitability for all the sectors sub-samples except for the insurance sub-sector companies. These results generally are similar to the previous studies results of (Niresh \& Velnampy, 2014; Banchuenvijit, 2012; Jonsson, 2007; Goddard, Molyneux \& Wilson, 2004; Shepherd, 1972).

Table 10. Assessing the effect of size on profitability of financial sub-sector firms using the second model

\begin{tabular}{lllll}
\hline \multicolumn{1}{c}{ Years } & $(2005-2011)$ & $(2005-2011)$ & $(2005-2011)$ & $(2005-2011)$ \\
& Bank & Diversified Financial & Insurance & Real state \\
& Sub-Sector Companies & Sub-Sector Companies & Sub-Sector Companies & Sub-Sector Companies \\
\hline Observations Number: & 112 & 181 & 161 & 183 \\
Constant (c) & 3.66 & -42.067 & -39.679 & -16.463 \\
t-statistic (Ho: 0) & 1.388 & -4.394 & -3.206 & -3.508 \\
p-value & 0.167 & 0 & 0.002 & 0 \\
LTRev $_{\text {it }}$ & 0.122 & 7.399 & 7.326 & 3.441 \\
t-statistic (Ho: 0) & 0.653 & 4.835 & 3.44 & 4.093 \\
p-value & 0.516 & 0 & 0 & 0 \\
LEV & -0.035 & -0.042 & -0.157 & -0.06 \\
t-statistic (Ho: 0$)$ & -1.537 & -1.187 & -1.993 & -1.862 \\
p-value & 0.128 & 0.237 & 0.048 & 0.065 \\
Adjusted $\mathrm{R}^{2}$ & 0.299 & 0.388 & 0.366 & 0.202 \\
F-Statistic & 3.063 & 4.085 & 3.804 & 2.15 \\
\hline
\end{tabular}

Based on the previous regression analysis results from Table 3 to Table 10 the second and third research sub-questions of this study, can be answered that the company size effect on its profitability is different for the different industry sectors during the period of study, and also the company size effect on its profitability is different for the different sub-sectors industry sectors during the period of study.

In the other hand it can be noted that the previous results of the financial sub-sector companies were not similar to the previous results of the industrial and the services sub-sector companies. These results are interested, and might be worthy for an additional research, but unfortunately this is beyond this study.

It is not wise to say that there are specific and clear reasons behind these results of the financial sub-sector companies comparing to industrial and services sub-sector companies. However, it is clear that there are other factors rather than size which are related to the profitability for these companies specifically for the findings of Table 9 concerning the company size effect on its profitability.

It can be noted also that the above previous results from Table 3 to Table 10 still not enough to be sure that the industrial and services large size companies are the only companies which have the significant positive effect on profitability because the sample of the companies for this study contains a different size companies from different sectors. In addition to that, it should be noted that the growing profits for the small size company can be used to make substantial changes during time like increasing its operations, develop its products and make new products, increase its ability for diversification, increase its competitiveness, increase its market share, and all of those changes of course need more size for the company.

The forth research sub-question of this study says: Is the effect of the company size on its profitability different for the top $30 \%$ companies of the same industry sectors comparing with the bottom $30 \%$ companies of the same industry sectors during the period of study?

In order to answer the mentioned forth research sub-question of this study, another panel regression analysis was done for the top $30 \%$ and bottom $30 \%$ for the companies of the main sample and the other three sub-samples respectively. The top and bottom $30 \%$ companies were selected according to its total assets for the first model, and according to its total revenues for the second model. 
Table 11 presents the analysis results for the top 30\% main pooled sample and its three sub-samples through using Equation (1) as it is mentioned above using the same previous procedure of the unbalanced panel regression analysis which is corrected for potential heteroscedasticity following (White, 1980).

Table 11. Assessing the effect of size on profitability using the first model for the top $30 \%$ companies

\begin{tabular}{lcccc}
\hline Years & $(2005-2011)$ & $(2005-2011)$ & $(2005-2011)$ & $(2005-2011)$ \\
\hline & $\begin{array}{c}\text { All Sectors } \\
\text { Sample }\end{array}$ & $\begin{array}{c}\text { Industrial Sector } \\
\text { Sample }\end{array}$ & $\begin{array}{c}\text { Services Sector } \\
\text { Sample }\end{array}$ & $\begin{array}{c}\text { Financial Sector } \\
\text { Sample }\end{array}$ \\
\hline Observations & 416 & 182 & 125 & 191 \\
Number: & & & & \\
Constant (C) & -21.18 & -71.460 & -71.491 & 2.644 \\
t-statistic (Ho: 0) & -3.111 & -5.832 & -3.281 & 0.393 \\
p-value & 0 & 0.000 & 0.002 & 0.695 \\
LTA & 3.871 & 10.656 & 10.117 & 0.441 \\
t-statistic (Ho: 0) & 4.264 & 6.562 & 3.591 & 0.501 \\
p-value & 0 & 0.000 & 0.001 & 0.617 \\
LEV & -0.137 & -0.162 & -0.156 & -0.058 \\
t-statistic (Ho: 0$)$ & -7192 & -6.187 & -3.864 & -2.456 \\
p-value & 0 & 0.000 & 0.000 & 0.015 \\
Adjusted $\mathrm{R}^{2}$ & 0.175 & 0.377 & 0.203 & 0.202 \\
F-Statistic & 0 & 0.000 & 1.753 & 2.236 \\
\hline
\end{tabular}

Table 11 showed that the regression results for the pooled sample of the top 30\% companies are approximately similar to the previous regression results for the main pooled sample as it is in Table 3, indicating that the coefficient of the logarithm of total assets variable is significant 3.871 which is not far than the same coefficient as it is in Table 3 which was equal to 4.774 . The leverage control variable is also consistent with the result in Table 3.

The analysis results for the first and second sub-samples of the top 30\% companies are also consistent and approximately similar to analysis results of the first and second sub-samples as it is in Table 3. However, it can be noted that the logarithm of total assets variable for the services sub-sector sample is higher by 5.456 . The leverage control variable is consistent with the result of the two sub-samples in Table 3. However, the logarithm of total assets variable for the third sub-sample of the financial sector of the top 30\% companies is not significant, and it is not consistent with results shown in the previous Table 3 , and indicated that there are no effect of the company size on its profitability. This result is approximately similar to the results of the financial sub-sector companies shown in Table 9.

A similar analysis was done for the same pooled sample of the top $30 \%$ companies, and the other three sub-sectors using the second model of total revenues as shown in Table 12.

Table 12 showed that the regression results for the pooled sample of the top $30 \%$ companies are not similar to the previous regression results for the main pooled sample as it is in Table 3, indicating that the coefficient of the logarithm of total revenues variable is not significant $(0.068)$ even though it is close to $(0.05)$ and the coefficient is 13.377. This result might be affected by the insignificant result of the financial sub-sector coefficient. The leverage control variable is still consistent with the result in Table 3.

The analysis results for the first and second sub-samples of the top 30\% companies are also consistent and approximately similar to analysis results of the first and second sub-samples as it is in Table 3.

The values of the logarithm of total revenues variable are not far and the leverage control variable still consistent with the result in Table 3 . The results of the third sub-sample of the top $30 \%$ companies concerning the financial sector are also inconsistent with the previous results shown in the Table 3, and indicated an insignificant coefficient with no effect of the company size on its profitability. 
Table 12. Assessing the effect of size on profitability using the second model for the top $30 \%$ companies

\begin{tabular}{lllll}
\hline Years & $(2005-2011)$ & $(2005-2011)$ & $(2005-2011)$ & $(2005-2011)$ \\
& $\begin{array}{l}\text { All Sectors } \\
\text { Sample }\end{array}$ & $\begin{array}{l}\text { Industrial Sector } \\
\text { Sample }\end{array}$ & $\begin{array}{l}\text { Services Sector } \\
\text { Sample }\end{array}$ & $\begin{array}{l}\text { Financial Sector } \\
\text { Sample }\end{array}$ \\
\hline $\begin{array}{l}\text { Observations } \\
\text { Number: }\end{array}$ & 416 & 182 & 125 & 191 \\
Constant (C) & -85.807 & -43.512 & -5.379 & 1.827 \\
t-statistic (Ho: 0) & -1.527 & -3.975 & -0.452 & 0.218 \\
p-value & 0.128 & 0.000 & 0.652 & 0.827 \\
LTRev $_{\text {it }}$ & 13.377 & 7.303 & 3.511 & 2.055 \\
t-statistic (Ho: 0) & 1.832 & 4.884 & 2.115 & 1.682 \\
p-value & 0.068 & 0.000 & 0.038 & 0.095 \\
LEV $_{\text {it }}$ & -0.210 & -0.166 & -0.324 & -0.200 \\
t-statistic (Ho: 0) & -11.162 & -5.522 & -6.016 & -6.875 \\
p-value & 0.000 & 0.000 & 0.000 & 0.000 \\
Adjusted $\mathrm{R}^{2}$ & 0.310 & 0.405 & 0.369 & 0.450 \\
F-Statistic & 3.006 & 3.867 & 2.726 & 4.794 \\
\hline
\end{tabular}

The same analysis was done for the bottom $30 \%$ companies using the first and second model.

Table 13 presents the analysis results for the bottom $30 \%$ main pooled sample and its three sub-samples through using Equation (1).

Table 13. Assessing the effect of size on profitability using the first model for the bottom $30 \%$ companies

\begin{tabular}{lllll}
\hline Years & $(2005-2011)$ & $(2005-2011)$ & $(2005-2011)$ & $(2005-2011)$ \\
\hline & $\begin{array}{l}\text { All Sectors } \\
\text { Sample }\end{array}$ & $\begin{array}{l}\text { Industrial Sector } \\
\text { Sample }\end{array}$ & $\begin{array}{l}\text { Services Sector } \\
\text { Sample }\end{array}$ & $\begin{array}{l}\text { Financial Sector } \\
\text { Sample }\end{array}$ \\
\hline $\begin{array}{l}\text { Observations } \\
\text { Number: }\end{array}$ & 416 & 182 & 125 & 191 \\
Constant (C) & -44.045 & -104.552 & -57.070 & 1.546 \\
t-statistic (Ho: 0) & -3.075 & -4.687 & -2.296 & 0.100 \\
p-value & 0.002 & 0 & 0.024 & 0.921 \\
LTA & 6.793 & 16.031 & 8.647 & 0.175 \\
t-statistic (Ho: 0) & 3.173 & 4.810 & 2.333 & 0.077 \\
p-value & 0 & 0 & 0.022 & 0.939 \\
LEV & -0.095 & -0.134 & -0.083 & -0.100 \\
t-statistic (Ho: 0) & -6.442 & -3.202 & -3.868 & -1.639 \\
p-value & 0 & 0.002 & 0 & 0.103 \\
Adjusted R & 0.182 & 0.228 & 0.365 & 0.334 \\
F-Statistic & 2.216 & 2.482 & 3.094 & 0 \\
\hline
\end{tabular}

Table 13 showed that the regression results for the pooled sample of the bottom $30 \%$ companies are approximately similar to the previous regression results for the main pooled sample as it is in Table (3), indicating that the coefficient of the logarithm of total assets variable of 6.793 is significant and higher a bit comparing to the coefficient value in Table 3 which was 4.774 . The leverage control variable is also consistent with the result in Table 3.

The analysis results for the first and second sub-samples of the bottom $30 \%$ companies are also consistent and similar to analysis results of the first and second sub-samples as it is in Table 3. However, it can be noted that the logarithm of total assets variable for both the industrial and the services sub-sectors samples are higher. The coefficient of the industrial sub-sector is higher by 6.782 , and the coefficient of the services sub-sector is higher by 3.986. The leverage control variable is also still consistent with the result in Table 3.

However, the logarithm of total assets variable for the third sub-sample of the financial sector of the bottom $30 \%$ companies is not significant, and not consistent with results shown in the previous Table 3, and indicated that there is no effect of the company size on its profitability similar to previous results for the same financial sector 
as mentioned in Table 11.

The previous significant and higher results of the pooled sample and the industrial and services sub-samples in Table 11 indicated that small size companies have also positive significant effect of the company size on its profitability and even stronger. These results are opposite to (Majumdar, 1997) study results who found that big companies have a higher profitability compared to small companies after testing the effect of both the company size and the company age on its profitability level for 1020 Indian companies. The results shown in Table 11 also indicated that the strong effect of the company size on its profitability is not for the large size companies only. The tested companies in Table 11 are the smallest total assets companies, and it is noted that even small size companies have a strong effect on its profitability, and those results supported the previous note that the growing profits for the small size company can be used to make substantial changes during time like increasing its operations, develop its products and make new products, increase its ability for diversification, increase its competitiveness, increase its market share, and all of those changes of course need more size for the company. In this case the profitability can affect the size of the company.

Table 14. Assessing the effect of size on profitability using the second model for the bottom $30 \%$ companies

\begin{tabular}{lllll}
\hline Years & $(2005-2011)$ & $(2005-2011)$ & $(2005-2011)$ & $(2005-2011)$ \\
\hline & All Sectors & Industrial Sector & Services Sector & Financial Sector \\
\hline Number of observations: & 416 & 182 & 125 & 191 \\
Constant (C) & -19.817 & -43.512 & -33.826 & -15.187 \\
t-statistic (Ho: 0) & -3.410 & -3.975 & -3.794 & -1.901 \\
p-value & 0.001 & 0.000 & 0.000 & 0.059 \\
LTRev $_{\text {it }}$ & 3.433 & 7.303 & 6.017 & 2.693 \\
t-statistic (Ho: 0) & 3.291 & 4.884 & 3.948 & 1.839 \\
p-value & 0.001 & 0.000 & 0.000 & 0.068 \\
LEV $_{\text {it }}$ & -0.069 & -0.166 & -0.092 & -0.028 \\
t-statistic (Ho: 0) & -2.681 & -5.522 & -6.266 & -0.841 \\
p-value & 0.008 & 0.000 & 0.000 & 0.401 \\
Adjusted $\mathrm{R}^{2}$ & 0.103 & 0.405 & 0.246 & 0.334 \\
F-Statistic & 1.621 & 3.867 & 2.264 & 0.000 \\
\hline
\end{tabular}

Table 14 showed that the regression results for the pooled sample of the bottom $30 \%$ companies are similar to the previous regression results for the main pooled sample as it is in Table 3, indicating that the coefficient of the logarithm of total revenues variable is significant, and also the leverage control variable is also still consistent with the result in Table 3.

The analysis results of the first and second sub-sector samples are also consistent and approximately similar to analysis results of the first and second sub-sector samples as in Table 3. The values of the logarithm of total revenues variable are not far, and the leverage control variable is also still consistent with the result in Table 3 .

The results of the financial sector in the third sub-sample of the bottom $30 \%$ companies are still inconsistent with the previous results shown in the Table 3 , and indicated an insignificant coefficient with no effect of the company size on its profitability. The previous results of the top and bottom $30 \%$ companies of the financial sector are consistent generally with the previous results of the detailed analysis results of the same financial sector, which means that there are other variables rather than size affecting profitability for these companies. According to these results, it's clearly that size is not always related to profitability, and this fact including small size companies, and big size companies as well.

\section{Conclusions}

This study examined the effect of the company size on its profitability for the entire Jordanian public companies listed in Amman Security Exchange during the period between 2005 to 2011 by using total assets and total revenues as a proxies for size and the return on total assets as a proxy for profitability by applying two different regression models on the sample of the study.

This study used unbalanced panel regression analysis to examine the effect of the company size on its profitability. Based on the results of the study, the following conclusions can be made: 
First, the two models of the study indicated a highly significant for the entire Jordanian public companies including all the industrial public sector companies, all the commercial public sector companies, and all the financial public sector companies public listed in Amman Security Exchange during the period between the year of 2005 to the year of 2011 .

Second, the results indicated that the company size coefficient representing by both the total assets and total revenues are significant for the main pooled sample and the other three different sectors sub-samples, and the results were consistent.

Third, the company size coefficient value for the industrial sector was the highest between the other three different sectors sub-samples of the study, then the services sub-sector, and lastly the financial sub-sector with the lower coefficient value for the company size.

Fourth, the results of the next detailed industry analysis of the sub-sector companies had revealed different values for the company size coefficient with the highest values for the industrial specifically the food and beverages companies, then the services sub-sector specifically the commercial and educational services companies, and lastly the financial sub-sector specifically the insurance companies.

Fifth, the results indicated that the bank companies, the diversified financial sub-sector companies, and the real estate sub-sector companies have insignificant values for the total assets coefficient of the company size. However, the bank companies only were insignificant for the total revenues coefficient of the company size.

Sixth, the results of the top and bottom $30 \%$ companies were consistent with the main pooled sample, and the main industrial and services sub-samples, but not for the main pooled sample using the total revenues. However, the results for the financial sub-sample were insignificant, and inconsistent with the results of the main financial sub-sample companies.

\section{References}

Abiodun, B. Y. (2013). The Effect of Firm Size on Firms Profitability in Nigeria. Journal of Economics and Sustainable Development, 4(5), 90-94.

Alexander, S. S. (1949). The effects of size of Manufacturing Corporation on the Distribution of Rate of Return. Review of Economics and Statistics, 229-235. http://dx.doi.org/10.2307/1927749

Amman Security Exchange. (ASE). Annual reports (2007-2011). Retrieved from http://www.ase.com.jo

Banchuenvijit, W. (2012). Determinants of Firm Performance of Vietnam Listed Companies. Academic and Business Research Instttute. Retrieved from http://aabri.com/SA12Manuscripts/SA12078.pdf

Bayyurt, N. (2007). İşletmelerde Performans Değerlendirmenin Önemi ve Performans Göstergeleri Arasındaki İlişkiler. Sosyal Siyaset Konferansları Dergisi, 53, 577-592.

Bhayani S. J. (2010). Determinant of Profitability in Indian Cement Industry: An Economic Analysis. South Asian Journal of Management, 17(4), 6-20.

Dahmash, F. N. (2013). Abnormal Earnings Persistence in the Jordanian Context. International Journal of Business and Management, 8(15), 33-43. http://dx.doi.org/10.5539/ijbm.v8n15p33

Dogan, M. (2013). Does Firm Size Affect the Firm Profitability? Evidence from Turkey. Research Journal of Finance and Accounting, 4(4), 53-59.

Fiegenbaum, A., \& Karnani, A. (1991). Output Flexibility-A Competitive Advantage for Small Firms. Strategic Management Journal, 12, 101-114. http://dx.doi.org/10.1002/smj.4250120203

Goddard, J., Molyneux, P., \& Wilson, J. (2004). The Profitability of European Banks: A Cross-Sectional and Dynamic Panel Analysis. The Manchester School, 72, 363-383. http://dx.doi.org/10.1111/j.1467-9957.2004.00397.x

Goddard, J., Tavakoli, M., \& Wilson, J. O. S. (2005). Determinants of Profitability in European Manufacturing and Service: Evidence from Dynamic Panel Model. Applied Financial Economics, 15, 1269-1282. http://dx.doi.org/10.1080/09603100500387139

Hall, M., \& Weiss, L. (1967). Firms Size and Profitability. The Review of Economics and Statistics, 319-331. http://dx.doi.org/10.2307/1926642

Helfat, C., Finkelstein, S., Mitchell, W., Peteraf, M. A., Singh, H., Teece, D. J., \& Winter, S. G. (2007). Dynamic Capabilities: Understanding Strategic Change in Organizations. Blackwell: Oxford, U.K.

Jónsson, B. (2007). Does the Size Matter? The Relationship between Size and Profitability of Icelandic Firms. 
Bifröst Journal of Social Sciences, 1, 43-55.

Karadeniz, E., \& İskenderoğlu, Ö. (2011). İstanbul Menkul Kıymetler Borsası'nda İşlem Gören Turizm İşletmelerinin Aktif Kârlılı̆̆ını Etkileyen Değişkenlerin Analizi. Turizm Araştırmaları Dergisi, 22(1), $65-75$.

Lee, J. (2009). Does Size Matter in Firm Performance? Evidence from US Public Firms. International Journal of the Economics of Business, 16(2), 189-203. http://dx.doi.org/10.1080/13571510902917400

Majumdar, S. K. (1997). The Impact of Size and Age on Firm-Level Performance: Some Evidence from India. Review of Industrial Organization, 12(2), 231-241. http://dx.doi.org/10.1023/A:1007766324749

Niresh, J. A., \& Velnampy, T. (2104). Firm Size and Profitability: A Study of Listed Manufacturing Firms. International Journal of Business and Management, 9(4), 57-64.

Nunes, P. J. M., Serrasqueiro, Z. M., \& Sequeira, T. N. (2009). Profitability in Portuguese service industries: a panel data approach. The Service Industries Journal, 29(5), 693-707. http://dx.doi.org/10.1080/02642060902720188

Ozgulbas, N., Koyuncugil, A. S., \& Yilmaz, F. (2006). Identifying the Effect of Firm Size on Financial Performance of SMEs. The Business Review, Cambridge, 6(1), 162-167.

Rajan \& Zingales. (1995). What Do We Know about Capital Structure? Some Evidence from International Data. Journal of Finance, 50.

Ravenscraft, D. J., \& Scherer, F. M. (1987). Life after Takeover. The Journal of Industrial Economics, 36(2), 147-156. http://dx.doi.org/10.2307/2098409

Saliha, T., \& Abdessatar, A. (2011). The Determinants of Financial Performance: An Empirical Test Using The Simultaneous Equations Method. Economics and Finance Review, 10(1), 1-19.

Scherer, F. M. (1973). The Determinants of Plant Sizes in Six Nations. Review of Economics and Statistics, 135-145. http://dx.doi.org/10.2307/1926988

Serrasqueiro, Z. S., \& Nunes, P. M. (2008). Performance and Size: Empirical Evidence from Portuguese SMEs. Small Business Economics, 31(2), 195-217. http://dx.doi.org/10.1007/s11187-007-9092-8

Shepherd, W. G. (1972). The Elements of Market Structure. The Review of Economics and Statistics, 54(1), 25-37. http://dx.doi.org/10.2307/1927492

Stekler, H. O. (1964). The Variability of Profitability with Size of Firm. Journal of American Statistical Association, 59, 1183-1193.

Stierwald, A. (2009). Determinants of Firm Profitability-The Effect of Productivity and its Persistence. Melbourne Institute of Applied Economic and Social Research.

White, H. (1980). A Heteroskedasticity Consistent Covariance Matrix Estimator and a Direct Test for Heteroskedasticity. Econometrica, 48(4), 817-838. http://dx.doi.org/10.2307/1912934

Wu, M. L. (2006). Corporate Social Performance, Corporate Financial Performance, and Firm Size: A Meta-Analysis. Journal of American Academy of Business, Cambridge, 8(1).

\section{Copyrights}

Copyright for this article is retained by the author(s), with first publication rights granted to the journal.

This is an open-access article distributed under the terms and conditions of the Creative Commons Attribution license (http://creativecommons.org/licenses/by/3.0/). 